\title{
Improving Students' Critical and Creative Thinking through Realistic Mathematics Education using Geometer's Sketchpad
}

\author{
Decy Dhayanti ${ }^{1)}$, Rahmah Johar ${ }^{2}$, Cut Morina Zubainur ${ }^{3)}$ \\ ${ }^{1,2,3)}$ Mathematics Education Department, Syiah Kuala University \\ Corresponding author: decydhayanti@gmail.com
}

\begin{abstract}
Learning can foster students' character as well as their understanding. Realistic Mathematics Education (RME) is one of learning approach to foster those competences. In this research, the learningbased RME will be supported by using the Geometer's Sketchpad. This study aims to improve the students' character through Realistic Mathematics Education using Geometer's Sketchpad on proportion topic and analyze the student's learning achievement. The subjects of this research are the 25 eighth grade students in one of public secondary school in Aceb Tamiang, Aceh. Instruments used in the study are character observation sheets and test to assess students' learning achievement. The data analysis technique used is descriptive analysis. The result of data analysis shows that the implementation of Realistic Mathematics Education using Geometer's Sketchpad in topic of proportion can improve student's critical and creative thinking. In addition student's learning achievement met the minimal mastery criteria.
\end{abstract}

Keywords: Realistic Mathemaitcs Education, Geometer's Sketchpad, Creative and Critical Thinking

\section{Introduction}

The 2013 curriculum mandates that the learning of mathematics in the classroom should be student-oriented, close to everyday life, and useful for their daily life (Permendikbud, 2014). This needs to be done as an effort to improve students' ability to understand, feel and utilize math in everyday life. Students are given the opportunity to be part of mathematics through learning activities for reinvent the mathematical idea from everyday problems based on their previous knowledge. Freudenthal (in van den Heuvel-Panhuizen, 2003) argues that mathematics is a human activity and needs to be linked significantly to the concept of everyday life of student. Involving students actively in learning in the classroom impact students interpret math as a daily activity. The closeness between students' experiences with the taught material will make it easier for students to understand math, so that learning becomes meaningful.

The purpose and vision of mathematics learning is to train students to understand, master, use, communicate mathematical concepts and foster good character in students. Therefore, students need to be trained to work independently and cooperate in groups, think critically, creatively, consistently, think logically, systematically, respect opinion, and be responsible. Independent, democratic, consistent, systematic characters can be trained in other subjects other than mathematics, but to train the critical and creative thinking 
character could not be separated from the mathematical role during the learning process (Guildford, 1975; Siswono, 2016).

Critical thinking is a part of reflective thinking and focuses on establishing what it believes (Baron and Strenberg, (Eds) 1987). So critical thinking defined as the ability to analyze, synthesize, and evaluate. While four components creative thinking is fluency, flexibility, originality and ellaboration (Torrance, 1984). Base on the theory, critical thinking indicator is developed for analyzing and evaluating arguments and evidence, clarifying, making considerations, making explanations, and identifying an assumption. Indicators of creative thinking are giving many ideas, reveals a new ways, developing ideas and generating alternative answers (Sumarmo, Hidayat, Zulkarnaen, Hamidah, Sariningsih, 2012).

Mathematics as an important lesson in school which has the same responsibilities as other subjects to train the student's character. Character training is done consistently by instilling habits and behaviors characterized through learning in the classroom. Characteristic habits and behaviors can be trained through interactivity and use student contribution in the discussion. Optimizing the interaction of students with students or teachers with students and by using student contribution in learning situations can be trained with critical and creative thinking (Ruseffendi, 1990; NCTM, 1999; Sumarmo et al., 2012).

Teachers are expected to integrate ICT as a learning medium for all subjects (Permendikbud, 2014). Therefore, teachers must master ICT to support learning in the classroom. Some examples of the use of ICT in learning in the form of power points, excel, online games, software, video learning, and e-learning. Examples of software that can be used in learning mathematics such as Macromedia, Maple, Autograph, Geogebra, Geometer's Sketchpad, Google SketcUp and others (Berezny, 2015; Johar, 2015). Utilization of ICT can help teachers develop student understanding, increase student interest, and improve mathematical skills (NCTM, 2008). Learning by integrating ICT can make it easier for teachers and students to learn dynamically and interactively (Rahman, 2008). The use of ICT in learning can encourage students to conduct investigations, help students find information, discover and understand the material more deeply, define mathematical procedures/processes, design and produce representations of their own knowledge. In addition, ICT can be utilized as a means of teacher or a medium of learning.

The use of ICT as a medium in learning mathematics provides an opportunity for students to present opinions based on empirical facts. Helping students expose alternative solutions, point out the strengths and weaknesses of a problem, and present new ways or new results are competencies to create students' critical thinking characters. Providing flexibility of students to convey ideas or other strategies, finding solutions and procedures that are profitable, revealing new ways, generating ideas/answers, developing an idea, and making mathematical models a competence to create creative students (Torrance, 1984; Siswono, 2016). One of the utilization of ICT in learning mathematics is by using the right mathematical software with the material being taught. Utilization of one software can help students to be more creative in finding solutions, responding critically and giving opinions and can contribute to the general form of a problem as a student product that can be used in solving problems. Canadian TIPS4RM (Gains, 2010) shows that comparable material can be taught with Geometer's Sketchpad software.

Implementation of meaningful math learning, close to student life, contemporary orientation, and integrating ICT to train the student's character requires an appropriate approach to the expected learning objectives to be achieved. An approach that can accommodate mathematical learning objectives, correlates human activity and 
mathematics significantly with orientation of building character with Geometer's Sketchpad.

Based on the $103^{\text {th }}$ Regulation of the 2014 Curriculum on Process Standards, to support the success of the learning implementation, teachers must develop instructional tools that will be used in the classroom. The lesson plans serve as a reference for teachers in conducting lessons that facilitate students to be able to interpret the situation through mathematical modeling, using information technology as well as connecting various mathematical concepts in order to facilitate students to develop their capabilities. The teacher-created device should be a learning device that suits the needs and demands of the current curriculum.

Based on the background of the problems that have been described, then the formulation of the problem in this study are:

1. How is the improvement of students' critical and creative thinking after implementation of Realistic Mathematics Education using Geometer's Sketchpad on proportion topic in junior high school?

2. How is the students' learning achievement after the implementation of Realistic Mathematics Education using Geometer's Sketchpad on proportion topic in junior high school?

\section{Research Methods}

Subjects in this study were a class of eighth grade students of the public junior high school in Aceh Tamiang, Aceh which consists of 25 students. This study was conducted by experimental research with one-group pretest-postest design. In this study, the researcher used character observation sheets and test learning achievement as the instruments to collect the data. Data processing technique used is descriptive analysis. The materials used in this study were obtained through developmental research of author (Dhayanti, 2017).

The indicators to measure the critical thinking are to present opinions based on facts, give alternative thought to the problems encountered and present new or updated ways or outcomes of what they already have. In addition, the indicators to measure the creative thinking are expressing new ways, generating many ideas or answers, developing an idea or product and creating a mathematical model. In this research, each indicator is scored by 1 if "never", 2 if "sometimes" and 3 if "often / more than once". The observation results of critical and creative thinking characters are tabulated and calculated using average formula. The average results obtained are converted based on the criteria presented in the following table (Widyoko, 2009)

Table 1.

Criteria of Critical and Creative Thinking

\begin{tabular}{cc}
\hline Interval Average Score & Criteria \\
\hline$X>2,6$ & Very Good \\
$2,2<X \leq 2,6$ & Good \\
$1,8<X \leq 2,2$ & Edequate \\
$1,4<X \leq 1,8$ & Poor \\
$X \leq 1,4$ & Very Poor \\
\hline
\end{tabular}

Based on the table, the students' critical and creative thinking is said to increase if the average score of each indicator increase from the previous learning. In addition, the students' learning outcomes are categorized as good if at least $80 \%$ of them gain the minimum score 70 . 


\section{Results and Discussion}

In this research, it has been conducted four times of learning by implementing the realistic mathematics using Geometer's Sketchpad. Table 2 presented the increasing of the critical thinking characters of students of each learning.

Table 2.

The Average Score of the Students' Critical Thinking

\begin{tabular}{|c|c|c|c|c|c|c|}
\hline \multirow{2}{*}{ No } & \multirow{2}{*}{ Indicator } & \multicolumn{4}{|c|}{ Learning } & \multirow{2}{*}{ Average } \\
\hline & & I & II & III & IV & \\
\hline 1. & Presenting opinion base on facts & 2,2 & 2,2 & 2,3 & 2,3 & 2,3 \\
\hline 2. & $\begin{array}{l}\text { Giving Alternative thought to the } \\
\text { problem base }\end{array}$ & 2,3 & 2,3 & 2,5 & 2,5 & 2,4 \\
\hline 3. & $\begin{array}{l}\text { Exposes new or update way or results } \\
\text { from what your already have }\end{array}$ & 2,0 & 2,3 & 2,3 & 2,5 & 2,3 \\
\hline
\end{tabular}

Table 1 showed that every indicator of critical thinking character increased in each learning. In the first indicator, presenting opinion base on facts, the average score of critical thinking increased from 2.2 in the first learning to 2.3 in the fourth learning. The average score of each learning is 2.3. According to the criteria of critical thinking in Table 1 , the category of the first indicator is good. Likewise, in the second indicator, giving alternative thought to the problem base, the average score also increased from 2.3 to 2.5. The average score of the indicator is 2.4 which is included in the good category. In the third indicator, exposes new or update way or results from what you already have, the average score increased from 2.0 to 2.5. The average score of the indicator is 2.3 which is also good category. The highest increase occured in the third indicator. The category of all indicator of the student's critical thinking character is good.

The information in the Table 1 is based on the result of the observation on the character of critical thinking. In the first learning, the students are still ashamed to expose their opinions, give alternative thinking, and describe new way to solve the problem. However, in the next learning, the students' character has been changed. The students are able to express and present their opinions based on facts and provide alternative solutions, then develop their ideas. This is apparent in student learning outcomes conducted at the end of the learning. Students appear to provide answers and critical alternatives in response to problems.

The result of the development of students' critical thinking characters appear in exposing opinions, giving alternative thoughts, and exposing new ways. Students are able to express and present their opinions based on facts and provide alternative solutions, then develop ideas for new ways. This appears in the student solutions for the following problems on Students' Activity Sheet (LAS). 


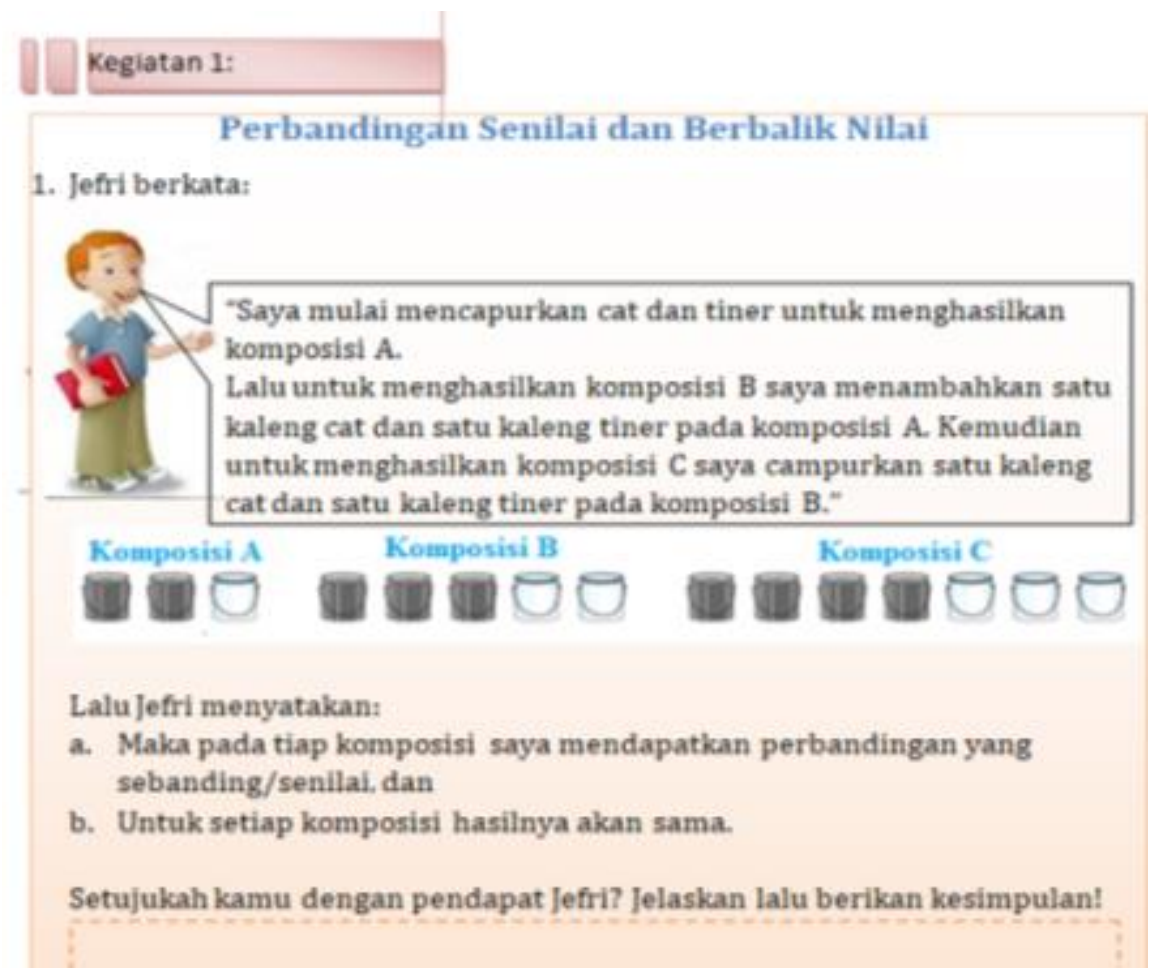

Figure 1. Example of Critical Thinking Problem on LAS 4 Activity 1

The above questions require that students to be able to differentiate between the direct proportion and the inverse proportion. It is expected that students are able to solve critical thinking problems by assessing arguments, providing alternative thoughts on problems encountered, and exposing opinion based on facts and providing new ways or results. The example of students-group answer about the first activity of the LAS is presented in the following figure.

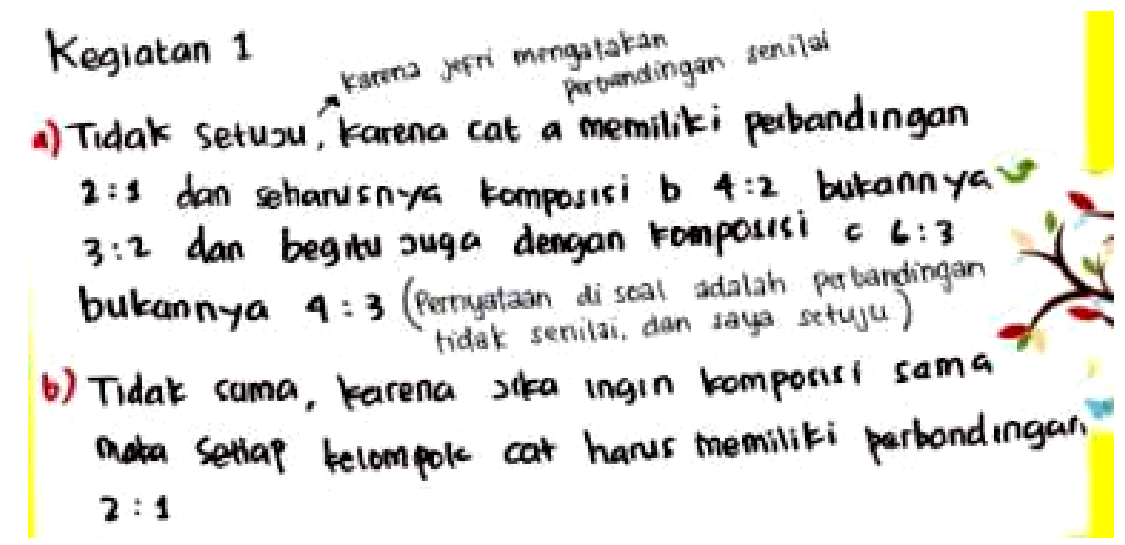

Figure 2. Example of Students-Group Answer on Critical Thinking Problems 


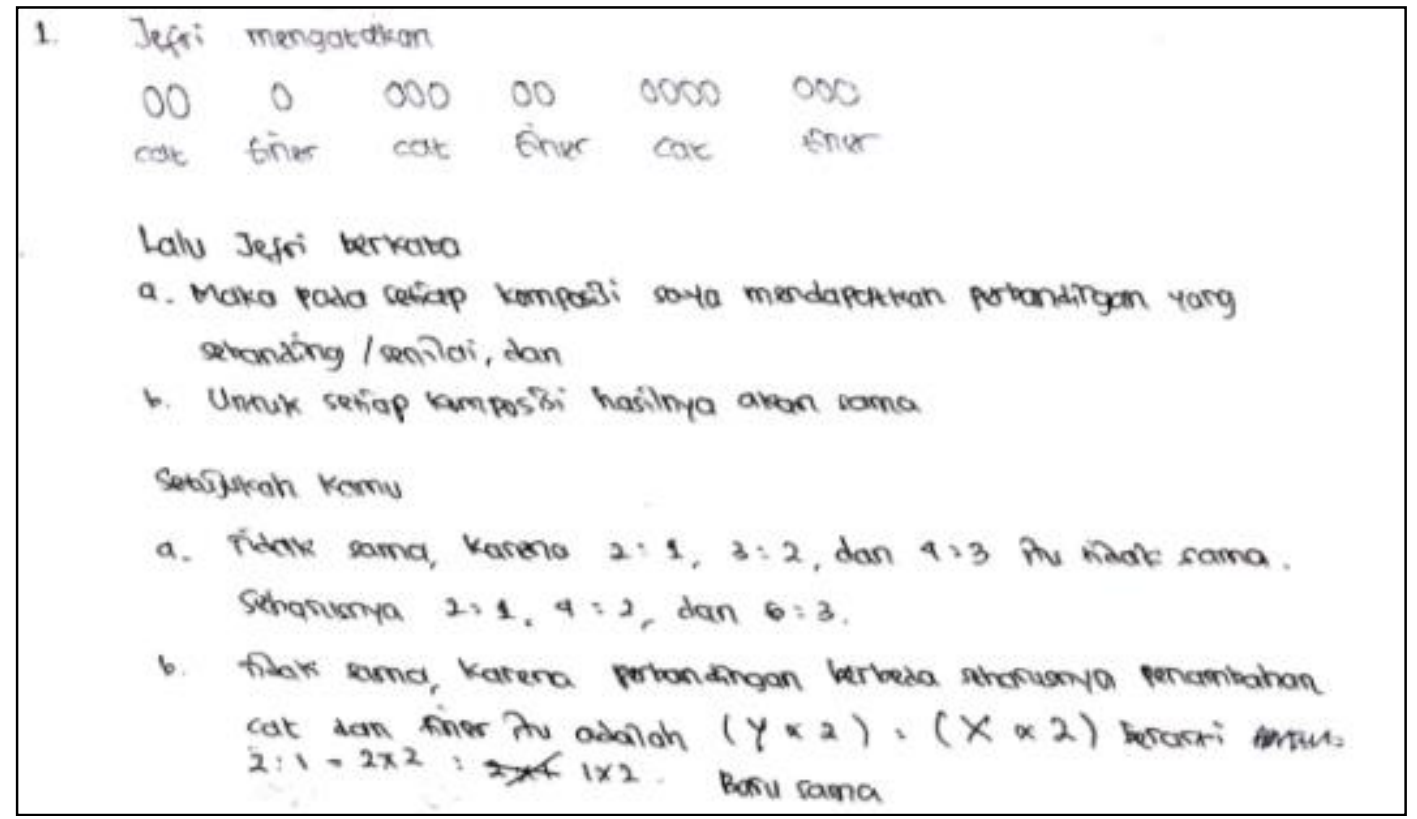

Figure 3. Example of Students-Group Answer on Critical Thinking Problems

The students answer in Figure 2 and 3 show that the students think critically by providing alternative thought to the problems at hand, exposing opinion based on facts and providing new ways or results. This increase is also showed in student class discussions. Students are able to come up the ideas, develop ideas and present opinions based on their own experiences.

Here in after, the improvement of students' creative thinking character can be seen in the following Table 3.

Table 3.

The Average Score of the Student Creative Thinking

\begin{tabular}{clccccr}
\hline \multirow{2}{*}{ No } & \multicolumn{1}{|c}{ Indicator } & \multicolumn{4}{c}{ Learning } & \multirow{2}{*}{ Average } \\
\cline { 3 - 6 } & & I & II & III & IV & \\
\hline 1. & Reveals a new way & 2,0 & 2,2 & 2,3 & 2,5 & 2,3 \\
2. & Give up many idea/answers & 2,2 & 2,3 & 2,5 & 2,5 & 2,4 \\
3. & Develop an idea or product & 2,2 & 2,3 & 2,3 & 2,5 & 2,3 \\
4. & Create a mathematics model & 2,0 & 2,3 & 2,4 & 2,5 & 2,3 \\
\hline
\end{tabular}

Table 3 shows that each indicator of the student's creative thinking increased in each learning. The average score of every indicator on the fourth learning is 2.5 . The first and fourth indicators increased about 0.5 point from the first to the fourth learning. The other indicator increased only 0.3 point. So, the score increase in the first and fourth indicators is higher than the second and third indicators. Overall, the average score of each indicator of the student's creative thinking is 2.3 which is included in the good category. The result of the average score on each indicator was supported by the findings of the observation in the classroom during the learning process.

In the first learning, the students did not familiar to express a new ways, because the students they have a limited experience to solve creative thinking problems. Previously, students are also rarely trained to make mathematical models, students are 
accustomed to solving routine problems. While in the second and third indicators, students' score are better because students try to give ideas and then developed them in their group. So score of the second and third indicators in the first learning is better than other indicators. During the observation of the character of creative thinking in the first learning, the students are able to make a mathematical model of the problem, expose various ways, and develop ideas based on his understanding by using Geometer's Sketchpad. Students are able to make decisions in many ways. In the other words, the model that has been constructed and Geometer's Sketchpad was able to help the students to make the choices.

The students learning outcomes was measured in the end of the fourth learning. Students appear to provide answers and critical alternatives in solving the problems. The development of the creative thinking character of the students emerge in expressing the new ways, giving many ideas, developing one idea to make a models. This character appears in the student solutions of the following problems.

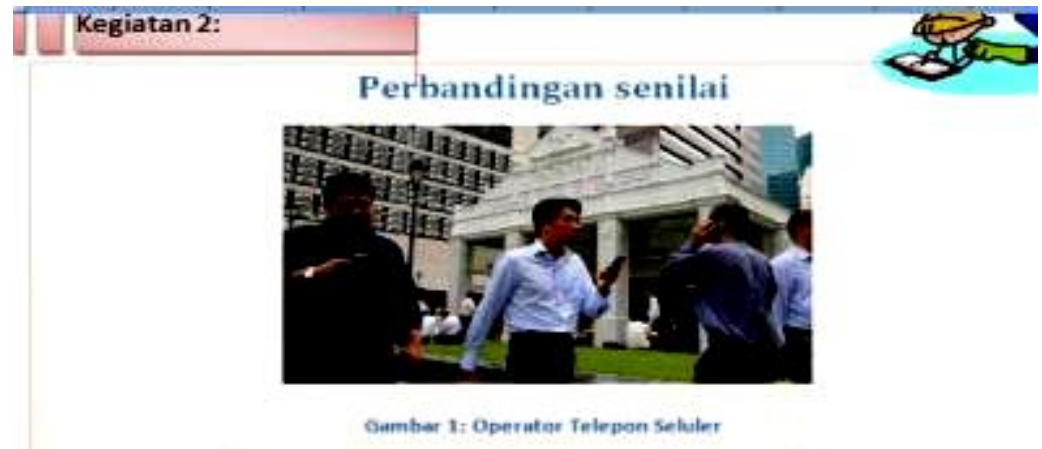

2. Dua perusahaan operator seluler menawarkan harga layanan telepon/panggilan untuk operator $A$ adalah $R p 99,000,00$ setiap bulan ditambah Rp10,00 tiap menit dan operator B adalah Rp1.000,00 tlap menit tanpa biaya bulanan.

a. Operator seluler manakah yang akan kamu gunakan? Tunjukkan caramu dalam mengambil keputusan! (coba-coba, tabel,grafik atau persamaan)

\section{Figure 4. Example of the Problem Creative Thinking on LAS 2 Activity 2}

The problem in the Figure 4 requires students to understand the proportion and able to apply their prior understanding. Students are expected to solve the problem on the second activity by various ways, for instance graphics, Geometer's Sketchpad, mathematical model, or their own way. The examples of the students' solutions for second activity of the LAS 2 are presented in Figure 5 and 6. 


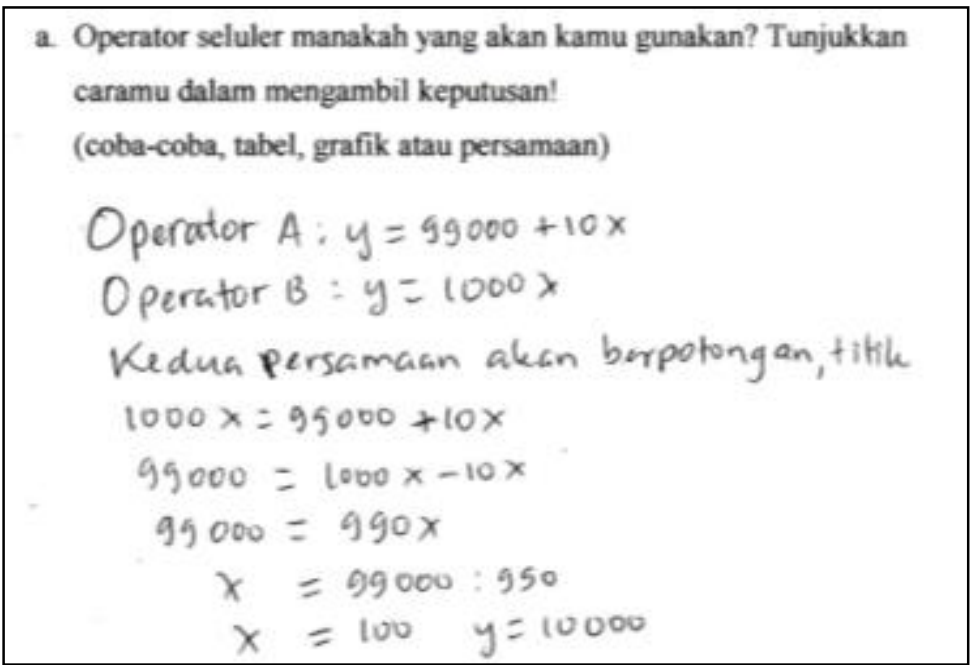

Figure 5. Example of the Student Solutions on LAS 2 Activity 2 using Mathematical Models

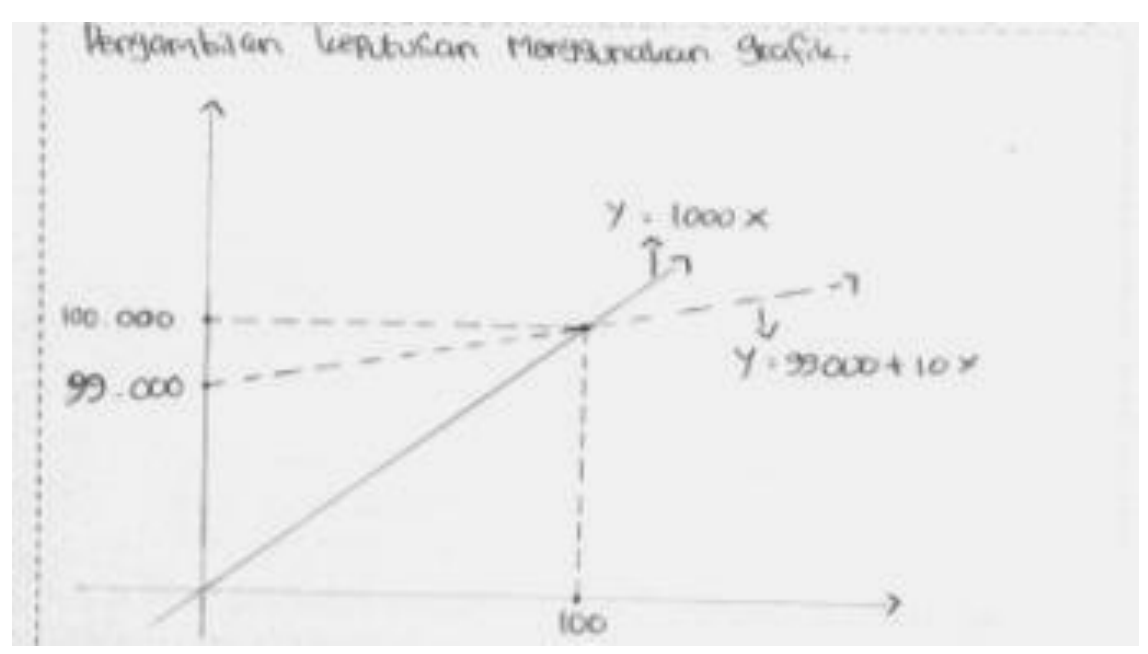

Figure 6. Example of the Students Solution on LAS 2 Activity 2 using Graphics

Figure 5 shows that the student used a mathematical model to decide which mobile phone to use. Another solution is given by trial and error and affirmed by graphics. In the figure 6 , the student used the charts to analyze the decisions to be taken.

During the group discussions, the students try to determine how much will be paid on each operator. The example of the trial and error solutions in the group discussions is presented in the following Figure 7. 


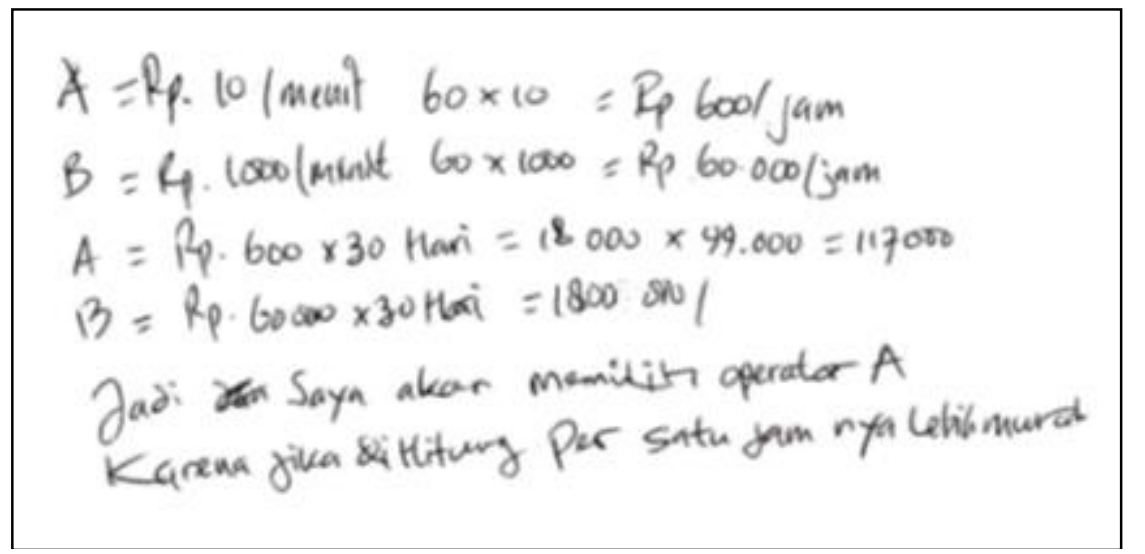

\section{Figure 7. Example of Students Solutions on LAS 2 Activity 2 using Trial and Error}

The trial and error methods used by the students for the first time is calculate the cost of calls for one hour/day on each operator. Then the students try to calculate the call cost on each operator for a longer time, which is 30 days. After the students use the trial and error method, mathematical model, tables and graphs, the students' group decision is presented as follows.

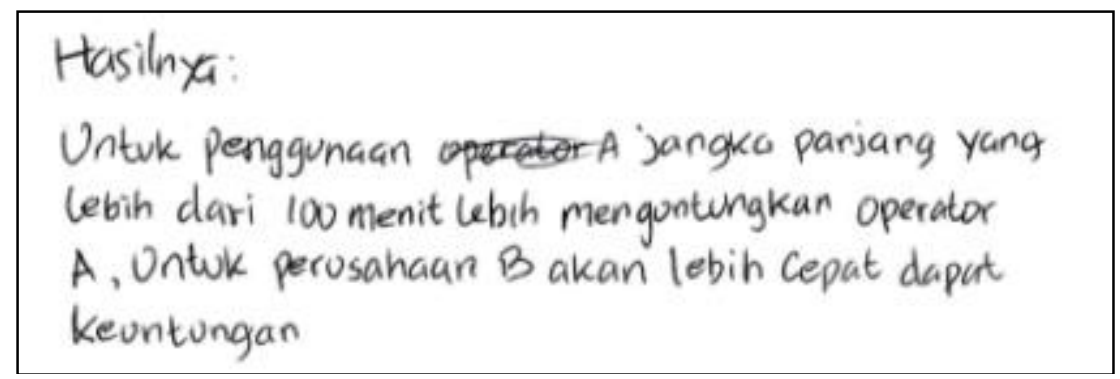

Figure 8. Students-Group Decision for LAS 2 Activity 2

Figure 8 shows that the students have decision to solve problem based on various ways. This is supported by the role of Geometer's Sketchpad to cultivate students' critical and creative thinking through realistic mathematics education.

Students' learning achievement is measured through written tests that were conducted after fourth learning. The average score obtained by students is 78.6 where 21 students (about 84\%) get a minimum score of 70 . On the other words, they are stated to have met the minimum standard of graduation. The high level of student learning achievement due to the teachers start the learning by using real problems and directing students to find the concept of comparison through group discussion. Students can distinguish between the direct and the inverse proportion through a Realistic Mathematics Education. In addition, the problem given is a non-routine, which is packaged to be more challenging using Geometer's Sketchpad so it becomes more interesting and useful. The learning ability gained is in accordance with the purpose and vision of mathematics learning in fostering the character of students.

The improving of the students' character of critical and creative thinking is inseparable from the role of a Realistic Mathematics Education using Geometer's Sketchpad. Geometer's Sketchpad help students to construct new understanding and develop the knowledge they already possess. Therefore, the critical and creative thinking 
indicators can emerge and increase at each learning such as exposing opinion based on facts and providing alternative thinking on the given problem. The Interaction, part of realistic education, helps the students to find and describe various ways to solve problems with Geometer's Sketchpad help. Exploring Geometer's Sketchpad helps the students to develop their thinking so that not limited to one solution only (Cangelosi, 1996). It showed that the use of ICTs can help teachers to develop students understanding, increase students' interest, and improve students' mathematical skills (NCTM, 2008). The Improving of the character of critical and creative thinking can be seen from the first learning until the fourth. The Indicators of critical and creative thinking arise during the learning process from the beginning of learning until the end.

According to Ausubel, the interrelationships between concepts in mathematics make learning activities more meaningful. In addition, the information have learned will be longer remembered by the students. The difference between the approach, the software used and the proposed problem is one of the supporters in determining the goals to be achieved in learning mathematics. The findings in this study are in accordance with the results presented by Kaput (1992) that the use of appropriate technology can develop students' critical and creative thinking. These results indicate that the geometer's realistic assisted geometer's sketchpad approach improves the student's character and learning outcomes in the subjects of proportion in junior high.

\section{Conclusion}

Based on the result of research and data analysis, it can be concluded: 1) the implementation of realistic mathematics education assisted of Geometer's Sketchpad on the proportion topic in junior high school can improve students' critical and creative thinking, 2) student's learning achievement meet the minimum standard of graduation or passing grade. The utilization of instructional media will be more effective if the teachers pay attention with the efficiency of the use of media in learning both in terms of time, the breadth of the topics, and attractiveness the media. The teachers are expected to improve students' ability in the use of the software and create an interactive classroom atmosphere so that the learning objectives can be achieved. The teachers can provide opportunities for students to perform mathematical activities in solving problems so that can improve the students' character and learning outcomes.

\section{Bibliography}

Berezny, S. (2015). What Software to Use in the Teaching of Mathematical Subjects?. Acta Didactica Napocensia. 8(1), 75-85.

Cangelosi, J. S. (1996). Teaching Mathematics in Secondary and Middle School: An Interactive Approach. New Jersey: Prentice Hall

Dhayanti, D. (2017). Pengembangan Perangkat Pembelajaran melalui Pendekatan Matematika Realistik berbantuan Geometer's Sketchpad di SMP. Tesis tidak diterbitkan. Unsyiah:Banda Aceh

Guildford, J. P. (1975). Varieties of creative giftedness, their measurement and development. Gifted Child Quarterly 19, 107 -121.

Johar, R. (2015). Pemanfaaatan Teknologi dalam Pembelajaran Matematika untuk Mengembangkan Profesionalitas Guru. Dalam Prosiding Peningkatan Profesionalisme Pendidik Matematika dalam menghadapi MEA 2015. Banda Aceh: Unsyiah

Johar, R. Zubaidah, T. dan Mariana, N. (2016) Upaya Guru Mengembangkan Karakter Students melalui Pembelajaran Matematika dengan Pendekatan Realistik pada Materi Perkalian. Jurnal Pendidikan Matematika, 10(1), 96-114. 
Kaput, J. J. (1992). Technology and Mathematics Education. In Growa, D.A (Ed) 1992. Handbook for Research in Mathematics Education. New York: McMillan.

Kemendikbud. (2014). Implementasi Kurikulum 2013, SMA Matematika. Jakarta: Badan Pengembangan Sumber Daya Manusia Pendidikan dan Kebudayaan dan Penjaminan Mutu Pendidikan

NCTM. (2008). Principles and Standards for School Mathematics. Virginia: NCTM.

Siswono, T.Y.E. (2016). Berpikir Kritis dan Kreatif sebagai Fokus Pembelajaran Matematika. Dalam Seminar Nasional Matematika dan Pendidikan Matematika (1 $1^{\text {st }}$ Senatik) Program Studi Pendidikan Matematika. FPMIPATI Universitas PGRI Semarang: Semarang

Small, M. (2011). Big Ideas from Dr, Small, Grade 4-8. Nelson Education: Canada

Sumarmo, U., Hidayat, W., Zulkarnaen, R., Hamidah., \& Sariningsih, R. (2012). Kemampuan dan Disposisi Berpikir Logis, Kritis dan Kreatif Matematik. Jurnal Pengajaran MIPA, 17(1). 17-33.

Syukur, I. A. (2014). Profesionalisme Guru dalam Mengimplementasikan Teknologi Informasi dan Komunikasi Di Kabupaten Nganjuk. Jurnal Pendidikan dan Kebudayaan, 20(2). 200-210.

TIPS4RM. (2010). Big Ideas and Questioning K-12: Proportional Reasoning. Ontario: Kanada

Torrance, E. P. (1984). Torrance Test of Creative Thinking. Bensenville, IN: Scholastic Testing Service.

Van den Heuvel-Panhuizen, Marija (2003).The Didactical Use of Models in Realistic Mathematics Education: An Example From A Longitudinal Trajectory On Percentage. Educational Studies in Mathematics, 54, 9-35. Kluwer Academic Publishers: Netherlands.

Widyoko, S.F.P. (2009). Evaluasi Program Pembelajaran: Panduan Praktis bagi Guru dan Calon Pendidik. Yogyakarta: Pusat Belajar 